ORIGINAL ARTICLE / ARTIGO ORIGINAL

Prevalence of cardiovascular risk factors in the population of Vitória according to data from VIGITEL and the National Health Interview Survey of 2013

\title{
Prevalência de fatores de risco cardiovascular na população de Vitória segundo dados do VIGITEL e da Pesquisa Nacional de Saúde de 2013
}

\author{
Mariana Veronez Borgo', Enildo Broetto Pimentel', Marcelo Perim Baldo",
} Juliana Bottoni de Souza'", Deborah Carvalho Maltalv (D), José Geraldo Mill'

\begin{abstract}
Objective: To compare the prevalence of cardiovascular risk factors in the adult population of Vitória, Espírito Santo, Brazil, in two surveys conducted by telephone interview (VIGITEL) or by clinic and laboratory exams during the National Health Interview Survey (NHIS). Method: Data were collected from adults ( $\geq 18$ years). In VIGITEL, 1,996 subjects (males $=38 \%$ ) were interviewed. In NHIS, home visit followed by clinical and laboratory tests was made with 318 individuals (males $=48 \%$ ) selected in 20 census tracts of the city. The prevalence of risk factors was adjusted to the estimated population of the city in 2013. Data are shown as prevalence and 95\% confidence interval (95\%CI). Results: Similar values of prevalence were found in VIGITEL and NHIS, respectively, for smoking (8.2\%; 95\%CI 6.7-9.7\% vs 10.0; 95\%CI 6.4 - 13.6\%) and hypertension $(24.8 \%$; $95 \%$ CI $22.6-27.0 \%$ vs $27.2 \%$; 95\%CI $21.8-32.5 \%)$. Statistical differences between surveys $(\mathrm{p}<0.01)$ were found for diabetes $(6.7 \%$; 95\%CI $5.6-7.9 \%$ vs $10.7 \%$; 95\%CI $7.1-14.5 \%)$, obesity (16.8\%; 95\%CI $14.1-18.1 \%$ vs $25.7 \%$; 95\%CI 20.4 - 30.9\%) and high cholesterol ( $\geq 200 \mathrm{mg} / \mathrm{dL})(20.6 \%$; $95 \% \mathrm{CI}$ $18.6-22.6 \%$ vs $42.3 \%$; $95 \%$ CI $36.9-47.7 \%)$. The prevalence of diabetes was also higher ( $<<0.01)$ in NHIS (6.7 vs $10.7 \%$ ). Conclusion: Prevalence of smoking and hypertension, but not obesity, was adequately detected in VIGITEL, because there might have been information bias related to body weight during telephone interviews. Data show the necessity to improve the diagnosis of dyslipidemias in primary care services, as the control of this risk factor is of utmost importance to prevent cardiovascular diseases.
\end{abstract}

Keywords: Hypertension. Obesity. Dyslipidemias. Diabetes mellitus.

'Department of Physiological Sciences, Center for Health Sciences, Universidade Federal do Espírito Santo - Vitória (ES), Brazil. "Department of Pathophysiology, Center for Biological and Health Sciences, Universidade Estadual de Montes Claros - Montes Claros (MG), Brazil.

"'Department of Public Health, Center for Health Sciences, Universidade Federal do Espírito Santo - Vitória (ES), Brazil.

IvDepartment of Surveillance of Noncommunicable Diseases and Illnesses and Health Promotion, Ministry of Health - Brasília (DF), Brazil.

Corresponding author: José Geraldo Mill. Departamento de Ciências Fisiológicas, Centro de Ciências da Saúde, Universidade Federal do Espírito Santo. Avenida Marechal Campos, 1.468, Maruípe, CEP: 29042-770, Vitória, ES, Brazil. E-mail: josegmill@gmail.com Conflict of interests: nothing to declare - Financial support: Department of Health Surveillance of the Ministry of Health. 
RESUMO: Objetivo: Comparar a prevalência de fatores de risco cardiovascular na população de Vitória (ES) em pesquisa autorreferida por contato telefônico (VIGITEL) ou por exames clínicos e laboratoriais realizados na Pesquisa Nacional de Saúde (PNS). Método: Os inquéritos foram realizados na população adulta de Vitória ( $\geq 18$ anos). No VIGITEL foram entrevistados 1996 indivíduos (homens $=38 \%$ ). Na PNS foi feita visita domiciliar seguida de exames clínicos e laboratoriais em 318 indivíduos (homens $=48 \%$ ) selecionados em 20 setores censitários da cidade. Nos dois inquéritos, as prevalências foram ajustadas para a estrutura populacional estimada para o ano de 2013. Os dados são fornecidos como porcentagens e intervalo de confiança de 95\% (IC95\%). Resultados: Foram encontradas prevalências similares no VIGITEL e na PNS, respectivamente, para tabagismo (8,2\%; IC95\% 6,7 - 9,7\% versus 10,0; IC95\% 6,4 - 13,6\%) e hipertensão (24,8\%; IC95\% 22,6 - 27,0\% versus 27,2\%; IC95\% 21,8 - 32,5\%). Houve diferença estatística ( $\mathrm{p}<0,01)$ entre o VIGITEL e a PNS, respectivamente, para as prevalências de obesidade (16,8\%; IC95\% 14,1 - 18,1\% versus 25,7\%; IC95\% 20,4-30,9\%) e colesterol elevado ( $\geq 200 \mathrm{mg} / \mathrm{dL}$ ) no sangue (20,6\%; IC95\% 18,6 - 22,6\% versus 42,3\%; IC95\% 36,9 - 47,7\%). A prevalência de diabetes também foi maior $(\mathrm{p}<0,05)$ na PNS $(6,7$ versus 10,7\%). Conclusão: A prevalência populacional de hipertensão e tabagismo foi estimada adequadamente no VIGITEL. Isso não ocorreu com a obesidade por provável viés de informação do peso corporal no VIGITEL. Os dados mostram a necessidade de melhorar a cobertura diagnóstica das dislipidemias em vista da importância do controle desse fator de risco na prevenção primária das doenças cardiovasculares.

Palavras-chave: Hipertensão. Obesidade. Dislipidemias. Diabetes mellitus.

\section{INTRODUCTION}

Cardiovascular diseases (CVD) are the leading cause of death in Brazil and one of the features that most contribute to health spending and lost days of quality of life $\mathrm{e}^{1,2}$. CVDs are complex diseases, as they depend on both genetic predisposition and life habits ${ }^{3,4}$. Epidemiological studies showed that CVD can be prevented if one adopts healthy habits and, if diagnosed and treated early, they can be controled ${ }^{5}$.

Adopting adequate public policies for the diagnosis and treatment of CVD requires the continuous monitoring of the population aiming to determine the need and effectiveness of interventions. Epidemiological studies showed that cardiovascular morbidity and mortality can be reduced by means of adequate policies that control its main risk factors: tobacco use, hypertension, diabetes, dyslipidemia and overweight/obesity ${ }^{3,5}$. The INTERHEART study, for example, reported that about $90 \%$ of the risk attributable to myocardial infarction depends on a combination of only 9 risk factors, the previously mentioned ones included ${ }^{6}$. Therefore, monitoring these factors in the population is essential to guide public policies ${ }^{7}$.

To this end, the Ministry of Health has implemented a system of surveillance of risk factors for chronic noncommunicable diseases (NCDs) and has conducted, since 2006, an annual telephone survey (VIGITEL) in all State capitals and in the Federal District. The main objective of VIGITEL is to monitor life habits and both the prevalence and epidemiological 
characteristics of NCDs, including CVD and its risk factors, in the Brazilian population ${ }^{8}$. One of the limitations of VIGITEL is the fact that all information, including cardiovascular risk factors, is self-reported on a telephone interview. Easily identifiable risk factors, such as smoking, are presumed to be more accurately determined in this type of survey. However, the prevalence of risk factors whose diagnosis depends on clinical and laboratory tests may be inadequate due to information bias.

In 2013, a substudy of the National Health Interview Survey (NHIS) was conducted in Vitória, capital of Espírito Santo, aiming to determine salt intake by the adult population through 24-hour urine collection and the measurement of the sodium/creatinine ratio in a sample of casual urine ${ }^{9}$. The presence of cardiovascular risk factors was also determined by a home interview in the study, in addition to clinical and laboratory tests. Considering that both surveys were carried out with the same population and in the same year, our study aimed to compare the prevalence of risk factors, allowing a critical look at the validity of VIGITEL data, which, in addition to being nation-wide, are collected from a robust sample of the Brazilian population.

\section{METHOD}

Data from VIGITEL/ 2013 and NHIS-Vitória/ 2013 were used in the adult population of Vitória. VIGITEL was approved by the National Commission for Ethics in Research with Human Beings of the Ministry of Health (CONEP 355590) and the consent was obtained orally upon telephone contact with the interviewees. The NHIS-Vitória/ 2013 was approved by the Research Ethics Committee of the Health Sciences Center of the Federal University of Espírito Santo (UFES) (CEP/CCS 3243/2013), and all participants signed an informed consent form for data collection.

VIGITEL is conducted with a probabilistic sample of the adult population ( $\geq 18$ years) of each city where it is applied. In the 2013 survey, in Vitória, 3,800 telephone lines were drawn, of which 2,786 were eligible for the study, as they corresponded to household numbers. Upon contact by telephone, a resident of the domicile pertaining to the age group determined for the study was invited to participate. A total of 1,996 interviews (703 men and 1,263 women) were carried out with a questionnaire on sociodemographic and health-related information. Considering the discrepancy between the sample interviewed and the eligible population, prevalences were measured using estimates of age, sex and schooling for the population projected for the year of the survey ${ }^{10}$. The questionnaire had 83 questions on demographic and socioeconomic data, eating habits, life habits (physical activity, smoking, and alcohol consumption), anthropometric data (weight and height), self-reported health status and self-reported morbidity ${ }^{11}$.

The NHIS sample was obtained by drawing lots from 20 census tracts in Vitória. In each sector, 20 households were visited to find a volunteer (18 to 69 years of age). Recruitment in each sector was done by quotas, being $50 \%$ for each sex and $20 \%$ for each decade of 
age - the first included individuals aged 18 to 29 years. We did not include individuals who, at the time of home visit, were bedridden, with reduced mobility or difficulty in communication, in addition to pregnant or nursing mothers. A total of 396 individuals were recruited to answer the NHIS questionnaire at home to provide socio-demographic data (sex, schooling, self-reported race/color, monthly income, drug use, self-reported morbidity and life habits, including tobacco use).

Home visits were made by higher-education professionals (nursing and nutritionist) previously trained for the task. Upon visit, a day for clinical and laboratory tests, including 24-hour urine collection, would be scheduled. All exams were performed in a single day at the Cardiovascular Research Clinic of the Center for Health Sciences of UFES, no later than 15 days after home interview. Clinical exams (anthropometry and blood pressure measurement) were collected by previously trained nurses. A total of 326 individuals participated in the study, and complete data collection was obtained from 318 (80.3\% of the household sample). Further details of the study methodology and of the tests performed have already been published ${ }^{9,12}$.

At the clinical appointment, blood samples were collected for biochemical tests at a central laboratory (Tommasi Laboratory, Vitória), with certification from the Brazilian Society of Clinical Pathology. Weight information was obtained in a calibrated electronic scale (Toledo, Brazil) with accuracy of $0.1 \mathrm{~kg}$, and height was measured on a wall stadiometer (Seca, Germany) with precision of $0.1 \mathrm{~cm}$. The weight classification was based on body mass index (BMI), calculated by the relation of Quételet (weight/ height ${ }^{2}$ ). Blood pressure was measured in an appropriate room, with controlled temperature $\left(22-24^{\circ} \mathrm{C}\right)$ during the morning, after fasting and emptying of the bladder. Participants remained in rest for at least five minutes in sitting position.

The blood pressure was measured on the left arm using an oscillometer (Onrom 765CP IntelliSense, Japan) and a cuff apropriado to the circumference of the arm. From each participant, three measurements were taken at 1-minute intervals, and casual blood pressure was calculated with the mean of two last measurements. Patients with blood pressure $\geq 140 / 90 \mathrm{mmHg}$ or making use of antihypertensive were considered hypertensive. Diabetes was determined by the presence of fasting glycemia $\geq 126 \mathrm{mg} / \mathrm{dL}$ or report of current use of oral hypoglycemic and/or insulin. Dyslipidemia was characterized by the presence of total cholesterol equal to or greater than the borderline value $(\geq 200 \mathrm{mg} / \mathrm{dL})$ or current use of $\operatorname{statin}^{13}$.

\section{DATA ANALYSIS}

Continuous variables are presented as mean \pm standard deviation, and proportions are shown as percentages and $95 \%$ confidence interval (95\% CI). Considering the adoption of quotas by age range in sample selection during the NHIS, the populational prevalence of each risk factor was estimated from the structure of the population of Vitória projected for the 
year 2013, according to 2010 census data ${ }^{14}$. Risk factors, therefore, differ from the actual estimates for the target population. The comparison between means was done by the Student $t$ test for independent samples, and the comparison of proportions by the $\chi^{2}$ test. Statistical significance was set at $\mathrm{p}<0.05$.

\section{RESULTS}

Table 1 shows the sociodemographic characteristics of the sample addressed in the NHIS. The proportion of men and women was similar to the 2010 count. As expected from the

Table 1. Sociodemographic Features of the sample of the National Health Interview Survey, Vitória, Espírito Santo, Brazil, 2013.

\begin{tabular}{|c|c|c|c|}
\hline \multirow{2}{*}{$\mathrm{N}$} & Males & Females & All \\
\hline & 154 & 164 & 318 \\
\hline \multicolumn{4}{|l|}{ Age range (years) } \\
\hline $18-24$ & $12(7 \%)$ & $15(10 \%)$ & $27(8 \%)$ \\
\hline $25-34$ & $33(20 \%)$ & $33(21 \%)$ & $66(21 \%)$ \\
\hline $35-44$ & $28(17 \%)$ & $26(17 \%)$ & $54(17 \%)$ \\
\hline $45-54$ & $42(26 \%)$ & $35(23 \%)$ & $77(24 \%)$ \\
\hline $55-64$ & $37(23 \%)$ & $34(22 \%)$ & $71(22 \%)$ \\
\hline $65-70$ & $11(7 \%)$ & $12(8 \%)$ & $23(7 \%)$ \\
\hline \multicolumn{4}{|l|}{ Ethnicity/Skin color } \\
\hline White & $66(43 \%)$ & $76(46 \%)$ & $142(45 \%)$ \\
\hline Black & $18(12 \%)$ & $15(9 \%)$ & $33(10 \%)$ \\
\hline Brown & $68(44 \%)$ & $69(42 \%)$ & $137(43 \%)$ \\
\hline Other or NA & $2(1 \%)$ & $4(2 \%)$ & $6(2 \%)$ \\
\hline \multicolumn{4}{|l|}{ Schooling } \\
\hline $\begin{array}{l}\text { Elementary school } \\
\text { (up to } 8 \text { years) }\end{array}$ & $26(17 \%)$ & $37(23 \%)$ & $63(20 \%)$ \\
\hline $\begin{array}{l}\text { High school } \\
\text { (9-11 years) }\end{array}$ & 91 (59\%) & $88(54 \%)$ & $179(56 \%)$ \\
\hline $\begin{array}{l}\text { Higher education } \\
\text { ( } \geq 12 \text { years) }\end{array}$ & $36(23 \%)$ & $38(23 \%)$ & $74(23 \%)$ \\
\hline No information & $1(1 \%)$ & $1(1 \%)$ & $2(1 \%)$ \\
\hline
\end{tabular}

$\mathrm{N}$ : number of individuals; NA: no answer. 
adopted model of sample selection (quota by age group), the age distribution differs in relation to the population, with higher proportional inclusion of people in older age ranges. The other sociodemographic characteristics (self-reported race/skin color and schooling) had distribution similar to that of the census of Vitória in $2010^{14}$.

The clinical and laboratory characteristics of the NHIS sample are listed in Table 2. As expected, women had lower $(\mathrm{p}<0.05)$ weight and height, as well as lower values of creatinine, uric acid and systolic pressure, and higher values of high-density lipoprotein (HDL-c). All other variables were similar between genders. Overweight (BMI $\geq 25 \mathrm{~kg} / \mathrm{m}^{2}$ ) was detected in $63.3 \%$ (95\%CI $58.0-68.6 \%$ ) of participants, with $25.7 \%$ (95\% CI $21.1-$ $30.7 \%$ ) of the sample being considered obese (BMI $\geq 30 \mathrm{~kg} / \mathrm{m}^{2}$ ).

Of the 111 hypertensive participants in the sample, 65 were on antihypertensive medication and 44 had controlled blood pressure $(<140 / 90 \mathrm{mmHg})$, with $68 \%$ control. Awareness of hypertension was reported by $64 \%$ of hypertensive participants upon clinical appointment. Thus, as for hypertension, blood pressure control was close to $40 \%$. Thirty-four patients with diabetes (prevalence of 10.7\%; 95\%CI: $7.3-14.1 \%$ ) were identified, $26(76 \%)$ of whom had reported this condition upon home visits. Of these, 25 were on medication and 9 had controlled glycemia $(\leq 125 \mathrm{mg} / \mathrm{dL})$. Thus, glycemic

Table 2. Clinical and laboratory characteristics of individuals taking the National Health Interview Survey, Vitória, Espírito Santo, Brazil, 2013.

\begin{tabular}{l|c|c|c} 
& Males & Females & All \\
\cline { 2 - 4 } & $\mathrm{N}=154$ & $\mathrm{~N}=164$ & $\mathrm{~N}=318$ \\
\hline Age (years) & $44.3 \pm 14.2$ & $45.1 \pm 13.8$ & $44.8 \pm 13.9$ \\
\hline Weight $(\mathrm{kg})$ & $80.8 \pm 14.6$ & $68.7 \pm 27.3^{*}$ & $74.6 \pm 15.3$ \\
\hline Height $(\mathrm{cm})$ & $173.2 \pm 7.1$ & $158.8 \pm 6.1^{*}$ & $165.8 \pm 6.8$ \\
\hline BMl $\left(\mathrm{Kg} / \mathrm{m}^{2}\right)$ & $26.8 \pm 5.2$ & $27.4 \pm 5.2$ & $27.1 \pm 5.2$ \\
\hline SBP $(\mathrm{mmHg})$ & $125 \pm 14$ & $119 \pm 17^{*}$ & $122 \pm 16$ \\
\hline DBP $(\mathrm{mmHg})$ & $76 \pm 9$ & $75 \pm 9$ & $76 \pm 9$ \\
\hline HR $(\mathrm{bpm})$ & $66 \pm 10$ & $69 \pm 10$ & $68 \pm 10$ \\
\hline Glycemia $(\mathrm{mg} / \mathrm{dL})$ & $97 \pm 22$ & $95 \pm 28$ & $96 \pm 25$ \\
\hline Creatinine $(\mathrm{mg} / \mathrm{dL})$ & $0.92 \pm 0.16$ & $0.72 \pm 0.15^{*}$ & $0.82 \pm 0.16$ \\
\hline Uric Acid $(\mathrm{mg} / \mathrm{dL})$ & $5.8 \pm 1.2$ & $4.6 \pm 1.2^{*}$ & $5.2 \pm 1.2$ \\
\hline Cholesterol $(\mathrm{mg} / \mathrm{dL})$ & $188 \pm 40$ & $186 \pm 28$ & $187 \pm 39$ \\
\hline HDL-c $(\mathrm{mg} / \mathrm{dL})$ & $44 \pm 12$ & $51 \pm 12^{*}$ & $47 \pm 12$ \\
\hline Triglycerides $(\mathrm{mg} / \mathrm{dL})$ & $136 \pm 82$ & $122 \pm 56$ & $129 \pm 69$ \\
\hline
\end{tabular}

Values expressed as mean \pm standard deviation. ${ }^{*} p<0.05$ versus men (Student t-test); BMI: body mass index; SBP: systolic blood pressure; DBP: diastolic blood pressure; HR: heart rate; HDL-c: high density lipoprotein. 
control occurred in $36 \%$ of diabetic patients under treatment and comprised only $26 \%$ of all patients. The prevalence of high total cholesterol was $42.3 \%$ (95\%CI $36.9-47.7 \%$ ), and the condition was reported by only $43 \%$ of interviewees. Only 29 were on statin, of which $23 \mathrm{had}$ it under control ( $<200 \mathrm{mg} / \mathrm{dL})$. Of 289 subjects not on statin use, $107 \mathrm{had}$ total cholesterol $\geq 200 \mathrm{mg} / \mathrm{dL}$, of which $29 \mathrm{had}$ values $\geq 240 \mathrm{mg} / \mathrm{dL}$. As the frequency of statin use among patients with high cholesterol was low $(21.3 \%)$, only $17 \%$ of them were found to have this risk factor controlled.

The comparison of risk factors prevalence by gender in both surveys is shown in Table 3. It is interesting to note that, when it comes to obesity, the prevalence found in women was higher in NHIS, in which BMI was calculated from the measures of weight and height. On the other hand, measures in VIGITEL were self-reported. High cholesterol was seen more frequently in both men and women NHIS, which certainly reflects the lack of knowledge about this risk factor by the population in general.

The comparison between prevalence of risk factors established in VIGITEL and in NHIS 2013 is shown in Figure 1. As the VIGITEL sample was more robust, composed of 1,996 subjects interviewed by telephone, the population prevalence values were estimated by post-stratification weights adjusted for schooling, gender and age features of the population. In NHIS, the population prevalence was estimated from the adjustments for the population of Vitória in the age range of 18 to 69 years. Smoking was self-reported in both surveys by telephone (VIGITEL) and in NHIS upon visit. the prevalence of smoking $(8.2 \%, 95 \%$ CI $6.7-9.7$ versus $10.4 \%, 95 \%$ CI $7.0-13.4 \%)$ and hypertension $(24.8 \%$; $95 \%$ CI 24.8 - $27.0 \%$ versus $27.2 \%$, 95\%CI 21.8 - 32.5\%) were similar in VIGITEL and NHIS, respectively. Regarding hypertension, both surveys had similar overall prevalence (27.9 versus $28.2 \%$, respectively), but tend to be different when adjusted for sex (Table 3 ). As

Table 3. Comparison between cardiovascular risk factors in VIGITEL and in the National Health Interview Survey by gender, Vitória, Espírito Santo, Brazil, 2013.

\begin{tabular}{l|c|c|c|c|}
\hline \multirow{2}{*}{ Hypertension } & \multicolumn{2}{|c|}{ VIGITEL } & \multicolumn{2}{c}{ NHIS } \\
\cline { 2 - 5 } & Males & Females & Males & Females \\
\hline Diabetes & $21.1 \%$ & $27.9 \%$ & $28.6 \%$ & $25.2 \%$ \\
\hline Obesity & $5.8 \%$ & $(25.1-30.7)$ & $(20.7-36.5)$ & $(20.0-30.5)$ \\
\hline \multirow{2}{*}{ Smoking } & $(3.9-7.1)$ & $(6.2-9.4)$ & $(3.0-12.34)$ & $(7.6-18.6)$ \\
\hline High cholesterol & $15.6 \%$ & $16.1 \%$ & $18.4 \%$ & $30.37 \%$ \\
& $(12.4-18.7)$ & $(13.3-18.8)$ & $(11.62-25.2)$ & $(22.8-37.9)$ \\
\hline & $17.6 \%$ & $6.5 \%$ & $10.3 \%$ & $8.9 \%$ \\
\hline
\end{tabular}

Data shown as frequency $\pm 95 \%$ confidence interval. Obesity was considered as body mass index $\geq 30 \mathrm{~kg} / \mathrm{m}^{2}$ and high cholesterol $\geq 200 \mathrm{mg} / \mathrm{dL}$. NHIS: National Health Interview Survey. 
for diabetes, VIGITEL reports a prevalence of $6.7 \%$ (95\%CI: $5.6-7.9 \%)$, which is lower $\left(\chi^{2}=23.0 ; \mathrm{p}<0.01\right)$ than data from NHIS $(10.8 \%$; 95\%CI $7.1-14.5 \%)$. It should be noted that diabetes was self-reported during household interviews by $9.3 \%(95 \% \mathrm{CI} 6.2-12.6 \%)$ of NHIS participants.

Significant differences between surveys were detected for obesity $\left(\mathrm{BMI} \geq 30 \mathrm{~kg} / \mathrm{m}^{2}\right)$ and high cholesterol. According to VIGITEL, the prevalence of obesity was $16.8 \%$ (95\%CI $14.1-$ $18.1 \%$ ), while in NHIS was $25.7 \%$ (95\%CI $20.4-30.9 \%$ ) (Figure 1). It should be noted that the greatest discrepancy between surveys was detected among women (Table 3), with prevalence of obesity as measured by anthropometric measurements, being virtually twice as high of data reported in telephone interviews.

The greatest difference was found in relation to high cholesterol, which was reported by $20.6 \%$ (95\%CI $18.6-22.6 \%$ ) in VIGITEL and found in 40.9\% (95\%CI $35.0-46,8 \%$ ) of NHIS participants (Figure 1). Differently from obesity and hypertension, the difference between surveys for high cholesterol were found in both men and women (Table 3). The prevalence of self-reported high cholesterol in the NHIS was $18.2 \%$ (95\%CI $14.0-22.4 \%$ ), which is similar to the findings of VIGITEL.

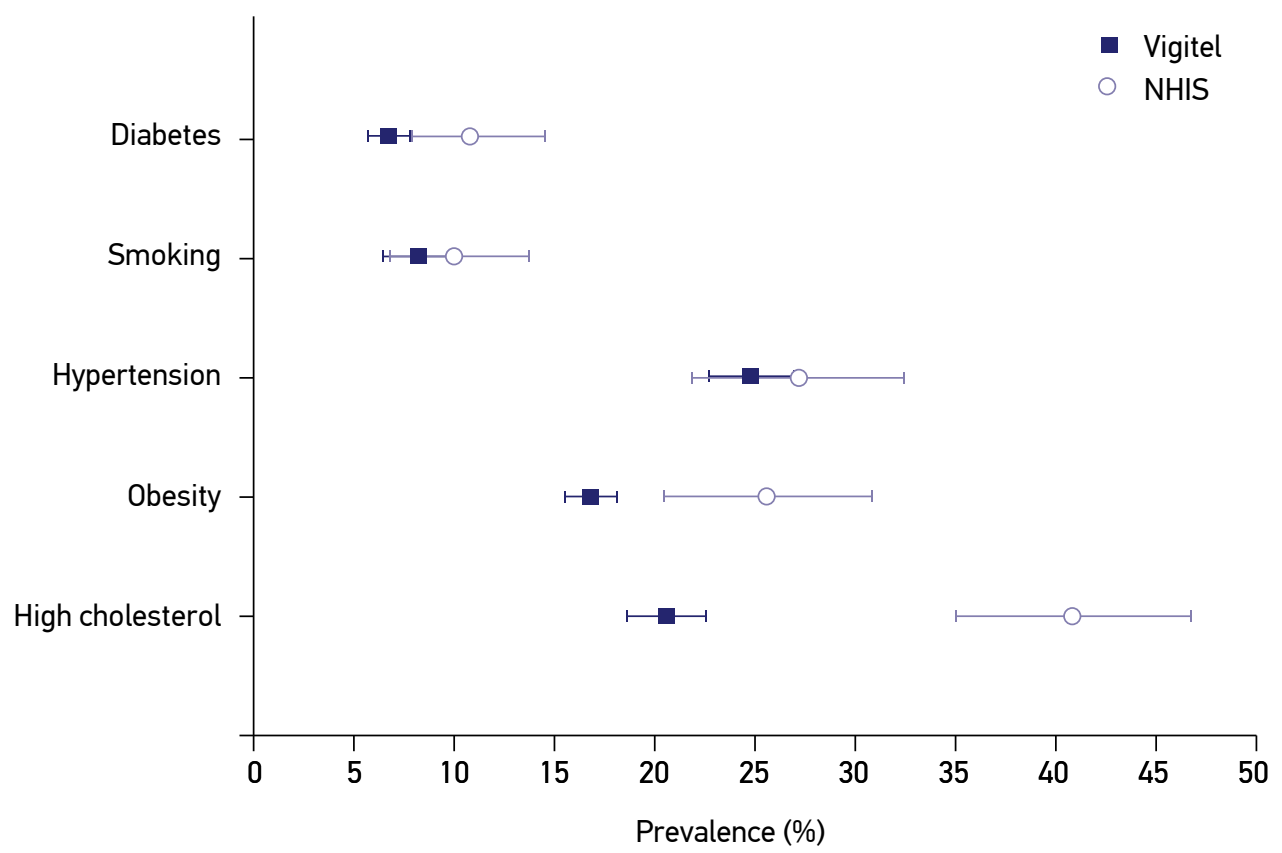

NHIS: National Health Interview Survey.

Figure 1. Prevalence of cardiovascular risk factors in VIGITEL and in the National Health Interview Survey conducted with the adult population of Vitória, Espírito Santo, Brazil, 2013.

Data shown as percentage and $95 \%$ confidence interval. 


\section{DISCUSSION}

The study presents the frequencies of indicators related to cardiovascular risk factors (smoking, obesity, hypertension, diabetes and high total cholesterol) in the city of Vitória, capital of Espírito Santo, according to data obtained from two surveys with different methodologies. In VIGITEL, data were collected based on a telephone interview, while in the substudy of the NHIS 2013, through a questionnaire applied in a home visit, followed by measurements and exams in a clinical setting. Comparing both surveys, smoking and hypertension had similar prevalence. For diabetes, there was a trend of higher prevalence in the NHIS. The prevalence ratios of obesity and high cholesterol, however, were markedly higher in NHIS, that is, when objective measures of these parameters were taken. In the case of obesity, the discrepancy was due to the lower prevalence in women reported in VIGITEL.

As to high cholesterol, however, under-reporting was identified in both sexes in VIGITEL, due to low level of knowledge about this condition by the population in general, once self-reported cholesterol was similar in the telephone interview (VIGITEL) and in the home interview (NHIS). Regarding diabetes, there was a sample difference that was not confirmed after adjusting for the age range of the population. This probably stems from the small number of individuals included in the NHIS, making it difficult to establish prevalence values below $10 \%$ with adequate statistical power.

Population surveys are fundamental to obtain information on health, adding importance to collective health planning and actions. Comparing different surveys poses methodological challenges ${ }^{15,16}$. In NHIS/Vitória, face-to-face interviews were conducted, while in VIGITEL data was obtained by telephone. In general, interviews are considered the gold standard in epidemiological research, since they allow collecting information about the health conditions more accurately. However, they also mean higher costs and present operational and logistical difficulties not faced in telephone surveys $\mathrm{s}^{16,17}$. These features are of great importance for epidemiological surveillance because of the ability to continuously monitor risk factors and behaviors, with regular intervals, in addition to being extremely agile and low-cost $\mathrm{t}^{11,15,18}$.

Comparison of prevalence data in different surveys is complex in view of sampling methodological differences, data collection strategies and time of field collection ${ }^{19}$. Even when identical questionnaires and definitions are used, differences can be related to understanding of questions; the presence of the researcher can improve understanding of formulated questions and options of answers, which may lead to findings closer to reality. On the other hand, as remote surveys (telephone, internet) are more impersonal, they may suit best for sensitive topics, such as alcohol and drug use, for example ${ }^{20}$. In spite of methodological differences, the NHIS lifestyle questionnaire followed a model similar to telephone survey, adopted at VIGITEL, although small variations were introduced in some questions. Regarding self-reported morbidity, however, questions and answer options were comparable in both surveys. 
Of the five indicators evaluated in more details, similar estimates were identified in three of them using the confidence interval for the population estimate: tobacco use and previous diagnosis of hypertension and diabetes. It is easy to understand the reproducibility of tobacco use data since individuals find no difficulties to report this habit in direct or telephone contact with the interviewer. For hypertension, the similarity of data suggests adequate diagnostic coverage of this risk factor in Vitória. As for diabetes, population prevalence data are weak because of the small sample size in NHIS.

As the diagnosis of hypertension is usually made in primary care, our data indicate good diagnostic coverage in the city. A similar result was obtained in a study comparing NHIS and the Behavioral Risk Factor Surveillance System (BRFSS) over the phone in the United States ${ }^{21}$. Another study carried out in Madrid, Spain, investigated behavioral risk factors and reported similarity between results obtained by telephone and in face-to-face interviews ${ }^{19}$. In Brazil, a study conducted in Belo Horizonte also showed similarities in the results of VIGITEL and household survey ${ }^{22}$. The comparative study IsaCAMP (Campinas, São Paulo) detected differences in prevalence estimates for arterial hypertension and osteoporosis between telephone and home surveys ${ }^{23}$.

In the NHIS-Brazil (2013), discrepancies between data reported and measured height and weight were also observed, resulting in prevalence of obesity among women about $20 \%$ higher after measurements ${ }^{24}$. This finding was confirmed in our study, with part of the difference accounting for the underestimation of weight in women. It is well-known that height data are overestimated and weight data are underestimated when obtained by self-report, with consequent underestimation of prevalence of obesity. An alternative to this situation was presented in a study conducted in Canada, in which data were collected directly and also by self-report. This helped to develop formulas to correct prevalence values obtained under different conditions based on the level of measurement error ${ }^{25,26}$. In our study, we pointed good agreement between self-reported values of height and weight in home interviews and objective measures at the clinic (data not shown). One possible explanation for this would be that NHIS participants, when interviewed at home, already knew that they would be re-assessed later on at the clinic, which would lead them to report their actual anthropometric measures.

The main finding of this study is the underestimation of prevalence of self-reported dyslipidemias. Although there are several types of dyslipidemias, we only analyzed data on total cholesterol because it is the element that is easier to understand by the general population. As the self-reported hypercholesterolemia values in VIGITEL and NHIS were similar, our results indicate that the low prevalence of high cholesterol reported in VIGITEL may be due to low diagnostic coverage of this risk factor, which would indicate a failure in primary care. These data corroborate the findings by an European Health Examination Survey Pilot Project, which showed underestimation in the self-reported prevalence of high cholesterol by both men and women when compared with 
direct measurement ${ }^{27}$. It is important to remember that several studies, including the BRFSS and the American Heart Association National Survey, use self-reported cholesterol levels as a tool to report the prevalence of dyslipidemia ${ }^{28,29}$. Our data suggest that this behavior would not be satisfactory if applied to the Brazilian population. In addition, they indicate the need to intensify efforts to improve diagnosis of dyslipidemias, as ischemic heart disease, whose incidence is strongly associated with dyslipidemias, is the leading cause of death in Brazil.

One of the limitations of this study was the difference in sampling methods and sample sizes of the surveys. Statistical power is relatively low (around $70 \%$ ) for the NHIS sample to detect differences of less than $5 \%$ in prevalence. In addition, the variation found in cholesterol levels in both investigations may be due to different cut-off points for high cholesterol as considered by participants of VIGITEL (self-reported) and NHIS ( $\geq 200 \mathrm{mg} / \mathrm{dL}$ in this study). Furthermore, the reduced size of the NHIS sample limits analysis by sex and age group. It is also possible that the discrepancies between diagnoses (self-reported and blood tests) are higher in younger age groups.

Therefore, our data suggest that, in conditions of high diagnostic coverage, as in the case of arterial hypertension, telephone surveys such as VIGITEL show good performance indices to determine prevalence. Regarding obesity, our data suggest information bias in VIGITEL. The good correlation between the weight and height reported in interviews and the measurements taken suggests that the interviewer's presence inhibits underestimation of weight by the interviewee.

It cannot be ruled out that some of the differences between surveys may reflect differences in schooling level and income, since landline ownership in the household is a social indicator generally associated to the population with higher schooling and income, although the use of factors for weighing of these variables in VIGITEL seeks to minimize social differences between families with and without residential landline.

\section{CONCLUSION}

Our findings allow us to conclude that VIGITEL has good accuracy to detect prevalence of smoking and hypertension, but it underestimates the prevalence of obesity and, mainly, dyslipidemia. The discrepancy in relation to obesity probably stems from weight information bias on a telephone-conducted survey. As for cholesterol, the main cause would be low diagnostic coverage of this condition for the population. Our data about diabetes require caution, since its prevalence in the population is low in comparison to the other factors and a trend to higher values was observed in NHIS in Vitória. Considering the impact of increased cholesterol on the incidence of ischemic diseases ${ }^{26,27}$, early diagnosis of this condition should be prioritized, especially in young adults ( $<45$ years), for ischemic heart disease is the main individual cause of death in Brazil. 


\section{REFERENCES}

1. Roth GA, Huffman MD, Moran AE, Feigin V, Mensah GA, Naghavi M, et al. Global and regional patterns in cardiovascular mortality from 1990 to 2013 . Circulation 2015; 132(17): 1667-78. https://doi.org/10.1161/ CIRCULATIONAHA.114.008720

2. Smith SC Jr, Chen D, Collins A, Harold JG, Jessup $\mathrm{M}$, Josephson $\mathrm{S}$, et al. Moving from political declaration to action on reducing the global burden of cardiovascular diseases: a statement from the global cardiovascular disease task force. Circulation 2013; 128(23): 2546-8. https:// doi.org/10.1161/ CIR.0b013e3182a93504

3. Ribeiro AL, Duncan BB, Brant LC, Lotufo PA, Mill JG, Barreto SM. Cardiovascular Health in Brazil: Trends and Perspectives. Circulation 2016; 133(4): 422-33. https:// doi.org/10.1161/ CIRCULATIONAHA.114.008727

4. Knight BS, Sunn N, Pennell CE, Adamson SL, Lye SJ. Developmental regulation of cardiovascular function is dependent on both genotype and environment. Am J Physiol Heart Circ Physiol 2009; 297(6): H2234-41. https: / / doi.org/10.1152/ajpheart.01338.2008

5. Yusuf S, Hawken S, Ounpuu S, Dans T, Avezum A, Lanas $\mathrm{F}$, et al. Effect of potentially modifiable risk factors associated with myocardial infarction in 52 countries (The INTERHEART Study): case-control study. Lancet 2004; 364(9438): 937-52. https: / / doi. org/10.1016/S0140-6736(04)17018-9

6. Tzoulaki I, Elliott P, Kontis V, Ezzatti M. Worldwide exposures to cardiovascular risk factors and associated health effects: Current knowledge and data gaps. Circulation 2016; 133(23): 2314-33. https:// doi. org/10.1161/CIRCULATIONAHA.115.008718

7. Schmidt MI, Duncan BB, Azevedo e Silva G, Menezes AM, Monteiro CA, Barreto SM, et al. Chronic noncommunicable diseases in Brazil: burden and current challenges. Lancet 2011; 377(9781): 1949-61. https: / / doi.org/10.1016/S0140-6736(11)60135-9

8. Brasil. Ministério da Saúde. Secretaria de Vigilância em Saúde. VIGITEL 2006: Vigilância de Fatores de Risco e Proteção para Doenças Crônicas em Inquérito Telefônico. Brasília: Ministério da Saúde; 2007.

9. Rodrigues SL, Souza Júnior PR, Pimentel EB, Baldo MP, Malta DC, Mill JG, et al. Relationship between salt consumption measured by 24 -h urine collection and blood pressure in the adult population of Vitória (Brazil). Braz J Med Biol Res 2015; 48(8): 728-35. https: / / dx.doi.org/10.1590\%2F1414-431X20154455

10. Graham, K. Compensating for missing survey data. Michigan: Ann Arbor; 1983.
11. Brasil. VIGITEL Brasil 2013: Vigilância de Fatores de Risco e Proteção para Doenças Crônicas por Inquérito Telefônico. Brasília: Ministério da Saúde, Secretaria de Vigilância em Saúde, Departamento de Vigilância de Doenças e Agravos Não Transmissíveis e Promoção da Saúde; 2014.

12. MillJG, RodriguesSL, Baldo MP, Malta DC, SzwarcwaldCL. Estudo de validação das equações de Tanaka e de Kawasaki para estimar a excreção diária de sódio através da coleta da urina casual. Rev Bras Epidemiol 2015; 18(Supl. 2): 22437. http: / / dx.doi.org/10.1590/1980-5497201500060020

13. Xavier HT, Izar MC, Faria Neto JR, Assad MH, Rocha VZ, Sposito AL, et al. V Diretriz Brasileira de Dislipidemias e Prevenção da Aterosclerose. Arq Bras Cardiol 2013; 101(4 Supl. 1): 1-22. http:/ / dx.doi. org/10.5935/abc.2013\$010

14. Instituto Brasileiro de Geografia e Estatística. Censo demográfico, 2010 [Internet]. [acessado em 16 jul. 2014. Disponível em: http:/ / www.ibge.gov.br/home/ estatistica/populacao/censo2010/default_resultados_ universo.shtm

15. Malta DC, Leal MC, Costa MFL, Morais Neto OL. Inquéritos Nacionais de Saúde: experiência acumulada e proposta para o inquérito de saúde brasileiro. Rev Bras Epidemiol 2008; 11(Supl. 1):159-67. http: / dx.doi. org/10.1590/S1415-790X2008000500017

16. Barros MBA. Inquéritos domiciliares de saúde: potencialidades e desafios. Rev Bras Epidemiol 2008; 11(Supl. 1): 6-19. http://dx.doi.org/10.1590/ S1415-790X2008000500002

17. Organização Mundial de Saúde. STEPwise approach to surveillance (STEPS) [Internet]. Organização Mundial de Saúde [acessado em 16 jul. 2014]. Disponível em: http:/ / www.who.int/chp/steps/en/

18. Bernal RTI, Malta DC, Araujo TS, Silva NN. Inquérito por telefone: pesos de pós-estratificação para corrigir vícios de baixa cobertura em Rio Branco, AC. Rev Saúde Pública 2013; 47(2): 316-25. http:/ / dx.doi. org/10.1590/S0034-8910.2013047003798

19. Galán I, Rodriguez-Artalejo F, Zorrilla B. Comparación entre encuestas telefónicas y encuestas "cara a cara» domiciliarias en la estimación de hábitos de salud y prácticas preventivas. Gac Sanit 2004; 18(Supl. 2): 440-50.

20. Malta DC, Bernal RTI, Mascarenhas MDM, Silva MMA, Szwarcwald CL, Morais Neto OL. Consumo de bebidas alcoólicas e direção de veículos nas capitais brasileiras e no Distrito Federal, segundo dois inquéritos nacionais de saúde. Rev Bras Epidemiol 2015 18(Supl. 2): 214-23. http: / / dx.doi.org/10.1590/1980-5497201500060019 
21. Nelson DE, Powell-Griner E, Town M, Kovar MG. A comparison of national estimates from the National Health Interview Survey and the Behavioral Risk Factor Surveillance System. Am J Public Health 2003; 93(8): 1335-41.

22. Ferreira AD, César CC, Malta DC, Andrade ACS, Ramos CGC, Proietti FA, et al. Validade de estimativas obtidas por inquérito telefônico: comparação entre Vigitel 2008 e Inquérito Saúde em Beagá. Rev Bras Epidemiol 2011; 14(Supl. 1): 16-30. http://dx.doi.org/10.1590/ S1415-790X2011000500003

23. Francisco PMSB, Barros MBA, Segri NJ, Alves MCGP, Cesar CLG, Malta DC. Comparação de estimativas para o auto-relato de condições crônicas entre inquérito domiciliar e telefônico - Campinas (SP), Brasil. Rev Bras Epidemiol 2011; 14(Supl. 1): 5-15. http: / / dx.doi. org/10.1590/S1415-790X2011000500002

24. Brasil. Ministério do Planejamento, Orçamento e Gestão. Instituto Brasileiro de Geografia e Estatística. Pesquisa Nacional de Saúde: Percepção do estado de saúde, estilos de vida e doenças crônicas: 2013. Rio de Janeiro: IBGE; 2014.

25. Connor Gorber S, Tremblay M, Moher D, Gorber B. A comparison of direct vs. self-report measures for assessing height, weight and body mass index: a systematic review. Obes Rev 2007; 8(4): 307-26. https: / / doi.org/10.1111/j.1467-789X.2007.00347.x

26. Connor Gorber S, Shields M, Tremblay MS, McDowell I. The feasibility of establishing correction factors to adjust self-reported estimates of obesity. Health Reports 2008; 19(3): 71-82.
27. Tolonen H, Koponen P, Mindell JS, Männistö S, Giampaoli S, Dias CM, et al. Under-estimation of obesity, hypertension and high cholesterol by selfreported data: comparison of self reported information and objective measures from health examination surveys. Eur J Public Health 2014; 24(6): 941-8. https: / / doi.org/10.1093/ eurpub/cku074

28. Centers for Disease Control and Prevention. Progress in chronic disease prevention factors related to cholesterol screening and cholesterol level awareness - United States, 1989. MMWR Morb Mortal Wkly Rep 1990; 39: 633-7.

29. Nash IS, Mosca L, Blumenthal RS, Davidson MH, Smith SC, Pasternak RC. Contemporary awareness and understanding of cholesterol as a risk factor. Arch Intern Med 2003; 163(13): 1597-600. https:// doi.org/10.1001/archinte.163.13.1597

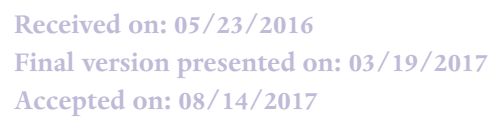

Author's contributions: Mariana Veronez Borgo: participated in the collection and analysis of the data and prepared the initial draft of the article. Enildo Broetto Pimentel: participated in data collection and analysis. Marcelo Perim Baldo: participated in the data analysis and revised the final version of the article. Juliana Bottoni de Souza: participated in data collection and analysis. Deborah Carvalho Malta: participated in the collection and analysis of the data and the design and final writing of the article; José Geraldo Mill: participated in the collection and analysis of the data and the design and final writing of the article. 